\title{
Characterization of mechanical properties of composite materials with filler coconut shell powder and sawdust with coconut fiber reinforcement as an alternative to low loaded brake friction materials
}

\author{
Anak Agung Alit Triadi * and Sujita Darmo \\ Mechanical Engineering, Engineering Faculty, Mataram University Jln. Majapahit No.62 Mataram Nusa Tenggara Barat \\ Pos code : 83125 .
}

Global Journal of Engineering and Technology Advances, 2021, 09(02), 017-023

Publication history: Received on 07 October 2021; revised on 10 November 2021; accepted on 12 November 2021

Article DOI: https://doi.org/10.30574/gjeta.2021.9.2.0148

\begin{abstract}
The purpose of the study is to determine the best composition variation of the fifth variation of the composition of the composite material against the wear test, hardness test, tensile test comparing values with the safety standards of the brake lining composite SAEJ 661.

Making the specimens was performed by mixing the ingredients with a mixer for 15 minutes and then do the process of compaction, with a load of 4 tons and detained achieve holding time is desired, then dies (mould) are placed in the oven and do the sintering process at a temperature of $150^{\circ} \mathrm{C}$ for 180 minutes and specimens removed from the mould, the process of finishing and testing.

These test results show that the composition of the material that is on variation $\mathrm{V}$ best price obtained 96.575 HBN hardness, wear rates of $1,29 \times 10^{-6} \mathrm{gr} /\left(\mathrm{mm}^{2}\right.$.detik), and a tensile strength of $0.842 \mathrm{MPa}$, but the brake friction material not meet safety standards SAEJ brake 661 .
\end{abstract}

Keywords: Brake lining; Organic materials; Mechanical testing; Composite

\section{Introduction}

The development of materials science, especially in the field of composite, essentially continues to develop along with human efforts to improve the welfare of their own lives. One aspect that needs to be considered in obtaining new materials is the use of materials derived from plants or organic fibers. Data from the Ministry of Forestry and Plantations in 1999/2000 showed that wood waste produced in Indonesia reached more than 5 million $\mathrm{m}^{3} /$ year [4]. One form of waste that is considered to have the potential to be developed is coconut shell and coconut fiber. According to the United Coconut Association of the Philippines (UCAP), which was reported by the Directorate General of Plantations [5], the national coconut plantation area of 3.78 million hectares is equivalent to Indonesia's ability to provide raw materials for processing coir and coconut shells for more than 10 million hectares [2]. 4 million tons per year, meanwhile, coconut shell has excellent durability, high roughness and abrasion resistance [6]. The friction materials currently on the market can be grouped into asbestos friction materials and non-asbestos friction materials. Asbestos friction material has been shown to cause cancer in industrial workers and consumers [13] and dust derived from para-aramid fibers can cause lung damage [3]. Therefore, friction materials from organic materials need to be developed. The description above also shows that the potential for large amounts of waste needs to be developed into more useful engineering products such

\footnotetext{
${ }^{*}$ Corresponding author: Anak Agung Alit Triadi

Mechanical engineering, Engineering Faculty, Mataram Universi Jln. Majapahit No.62 Mataram Nusa Tenggara Barat Kode Pos: 83125. 
as materials for low-load brake linings. Before being used as brake pads, various studies of physical-mechanical properties and variations in composite composition need to be carried out.

\section{Research Method}

\subsection{Materials}

Composite material is a material formed from a combination of two or more constituent materials through mixing, where the mechanical properties of each constituent material are different. Composite materials have better mechanical properties than metals, have high tailorability, have good fatigue strength, have higher specific strength (strength/weight) and specific stiffness (Young's modulus/density) [9]. Higher than metal, corrosion resistance, has heat and sound insulating properties, and can be used as a good electrical inhibitor, and can also be used to patch damage due to loading and corrosion [16].

\subsubsection{Coconut Shell Powder}

Coconut shell is one of the natural fillers that are widely available in tropical countries such as Indonesia, Malaysia, Thailand and Sri Lanka. Coconut is one part of agricultural products that have high economic value that can be used as a business base. Coconut shell is also an organic compound so that it can be decomposed by microorganisms (biodegradation) naturally in nature, and is also a potential source of natural fillers and has high economic prospects.

\subsubsection{Coconut Fiber}

Coconut is part of the mesocarp (blanket) in the form of coarse coconut fibers, coconut coir is a fairly large part of the coconut fruit, which is $35 \%$ of the total weight of the fruit. Coconut coir consists of fibers and cork that connect one fiber to another. Fiber is a valuable part of coir. Each coconut contains 525 grams of fiber (75\% of coir), and 175 grams of cork (25\% of coir) [14]. Coconut fiber obtained from the outer part of the coconut fruit (coconut coir) from the coconut tree (Cocusnucifera) belongs to the Arecaceae family (palm family), where this fiber is odorless, light, thick, strong and has abrasion resistance [8].

\subsubsection{Sawdust}

A lot of sawdust waste in our environment is wasted, not even used and only burned. Even though the burning of sawdust still has an impact on the environment [15]. A number of significant side effects include air pollution and environmental damage caused by inappropriate handling [7].

\subsubsection{Phenolic Resin}

In general, Phenolic resins are included in the Thermoset resin developed by Showa Highpolymer, based on its own technology in the mid-1960s. Phenolic resins were developed to improve characteristics that are difficult to cure (harden). Phenolic resins are usually in the form of styrene or acryl solutions. Unlike polyester resins, Phenolics can be hardened by diluting reactive monomers other than styrene monomer, because the main part of the reactive group consists of acylate or methacrylate radicals. The application of phenolics is widespread because it cures without any reactive monometer [10].

The materials used in this study were coconut shell powder, sawdust, and phenolic resin with a particle size of 50 mesh. Coconut fiber is used as reinforcement with a fiber length of $3 \mathrm{~mm}$.

The variations in the composition of the composite materials used are as follows:

- Coconut shell powder55\%, sawdust 20\%, coconut fiber $0 \%$, Resin $25 \%$

- Coconut shell powder $45 \%$, sawdust $20 \%$, coconut fiber $10 \%$, Resin $25 \%$

- Coconut shell powder 35\%, sawdust 20\%, coconut fiber $20 \%$, Resin $25 \%$

- Coconut shell powder 25\%, sawdust 20\%, coconut fiber 30\%, Resin $25 \%$

- Coconut shell powder $15 \%$, sawdust $20 \%$, coconut fiber $40 \%$, Resin $25 \%$ 


\subsection{Testing}

\subsubsection{Wear Testing}

This test aims to determine the wear value of the brake friction material test specimen against frictional resistance. In this test, the test specimen is mounted on a chuck and then given a load of $5.2 \mathrm{Kg}$ so that it rubs against the disk on the test equipment with a rotation of $1496 \mathrm{rpm}$ with a time of 60 seconds so that the level of wear can be known. The shape of the wear test specimen can be shown in the following figure 1

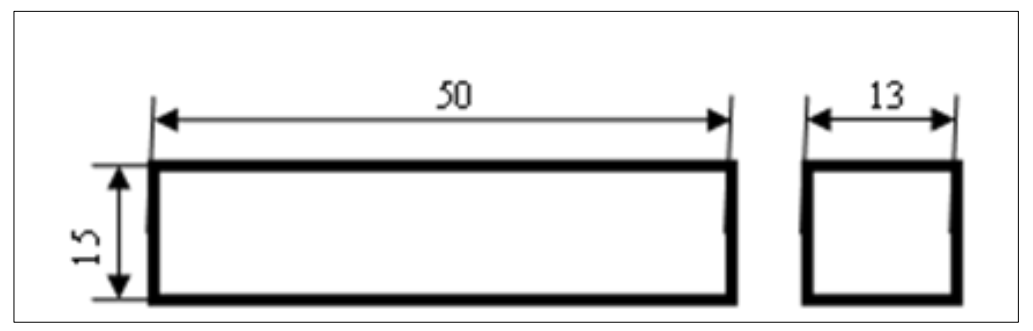

Figure 1 Form of wear test specimen (mm)

\subsubsection{Hardness Testing}

Hardness testing is one of the many tests used because it can be carried out on small specimens without difficulty regarding specifications. Of $2.5 \mathrm{~mm}$. The shape of the hardness test specimen can be shown in the following figure 2

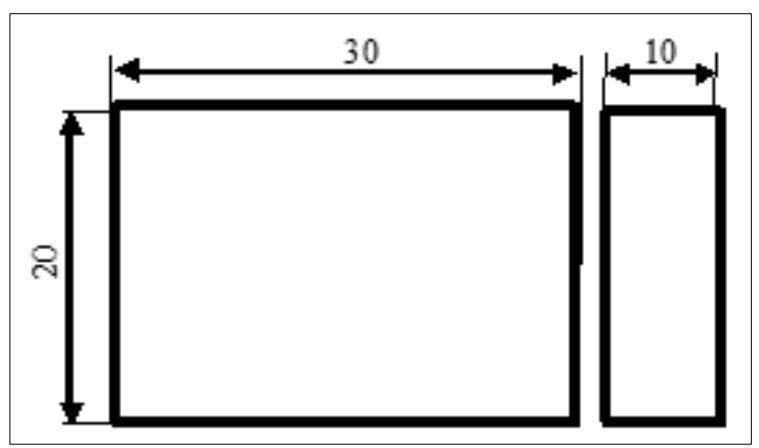

Figure 2 Form of hardness test specimen (mm)

\subsubsection{Tensile Testing}

Tensile testing is one of the stress-strain tests which aims to determine the strength of the material against a given tensile force [1]. In this test, the tool used is a Universal Tensile Machine brand Tensilon type RTG-1310 with a tensile speed of $1 \mathrm{~mm} / \mathrm{minute}$. The shape of the tensile test specimen can be shown in the following figure 3

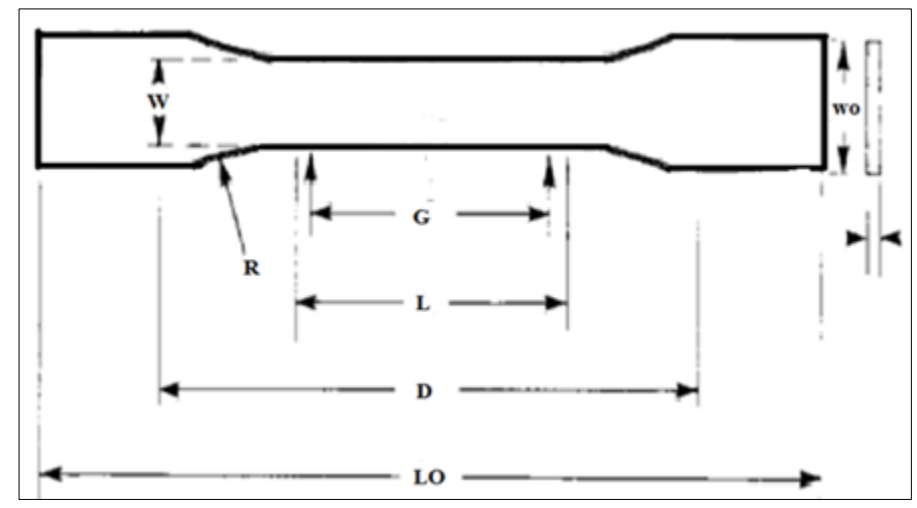

Figure 3 Form of tensile test specimen (ASTM Standard D 638) 


\section{Results and discussion}

\subsection{The result of the wear testing}

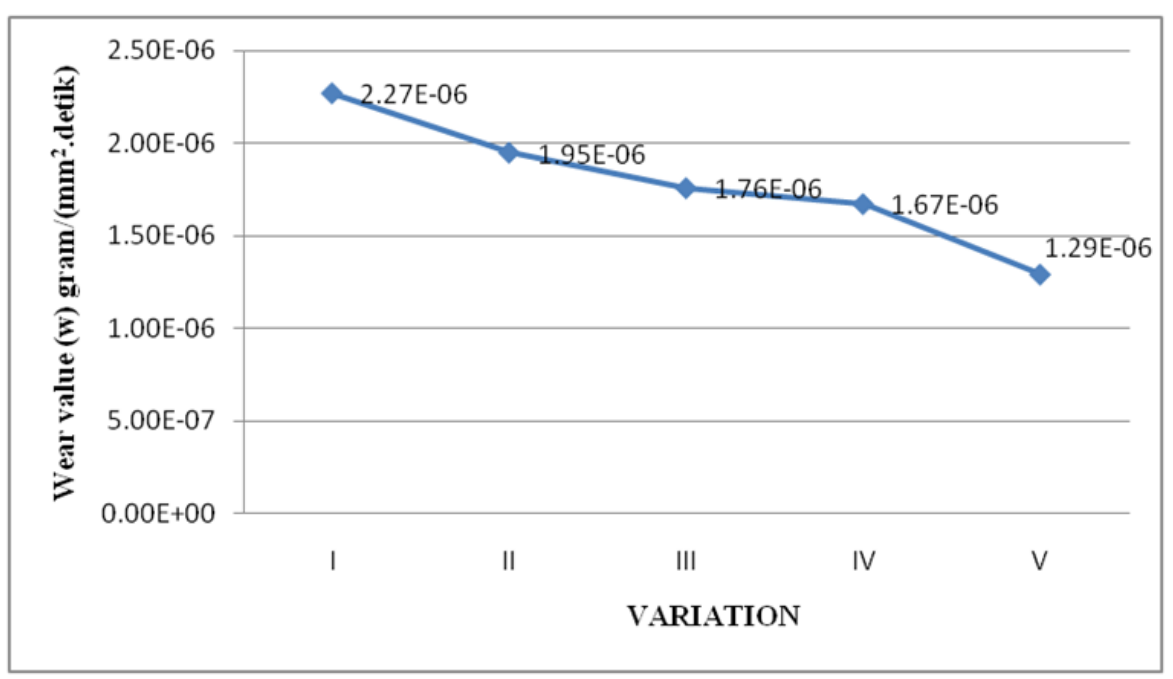

Figure 4 Graph of wear test

Based on the figure 4, test results of all specimens that have been carried out, the lowest wear value in variation IV is $1.29 \times 10^{-6} \mathrm{gr} / \mathrm{mm}^{2}$. s. While the highest wear value in variation I is $2.27 \times 10^{-6} \mathrm{gr} / \mathrm{mm}^{2}$. s. Referring to the safety standard of composite brake linings (SAE J661), namely with a wear value of $5 \times 10 \rrbracket \wedge(-3)-5 \times 10 \rrbracket \wedge(-4)\left(\mathrm{gr} / \mathrm{mm}^{\wedge} 2 . \mathrm{s}\right)$, the five variations of brake linings that has been tested has a wear value that is smaller than the brake lining safety standard,

\subsection{The result of the hardness test}

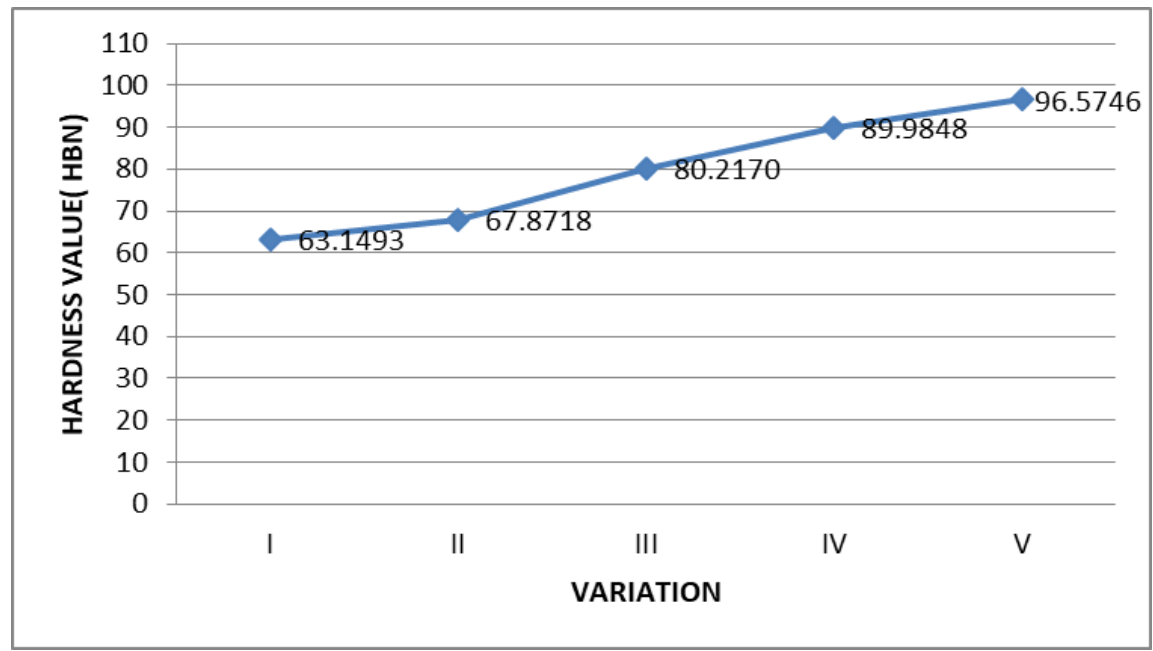

Figure 5 Graph of hardness test

In the figure 5, it can be seen in variation $V$ that the highest hardness value is obtained with a value of $96.985 \mathrm{HBN}$ while the lowest hardness value is in variation I with a value of $63,149 \mathrm{HBN}$, where the five variations of brake linings that have been tested have not met the hardness value of the SAEJ 661 brake lining safety standard.

\subsection{The result of the tensile test}

Referring to Figure 6 the graph of the tensile test results, the highest tensile strength value is obtained in the $\mathrm{V}$ variation of $0.842 \mathrm{~N} / \mathrm{mm}^{2}$, while the lowest tensile strength is obtained in the I variation with a value of $0.323 \mathrm{~N} / \mathrm{mm}^{2}$. Where the five variations of brake linings that have been tested have not met the tensile strength value of the SAEJ 661 brake lining safety standard. 


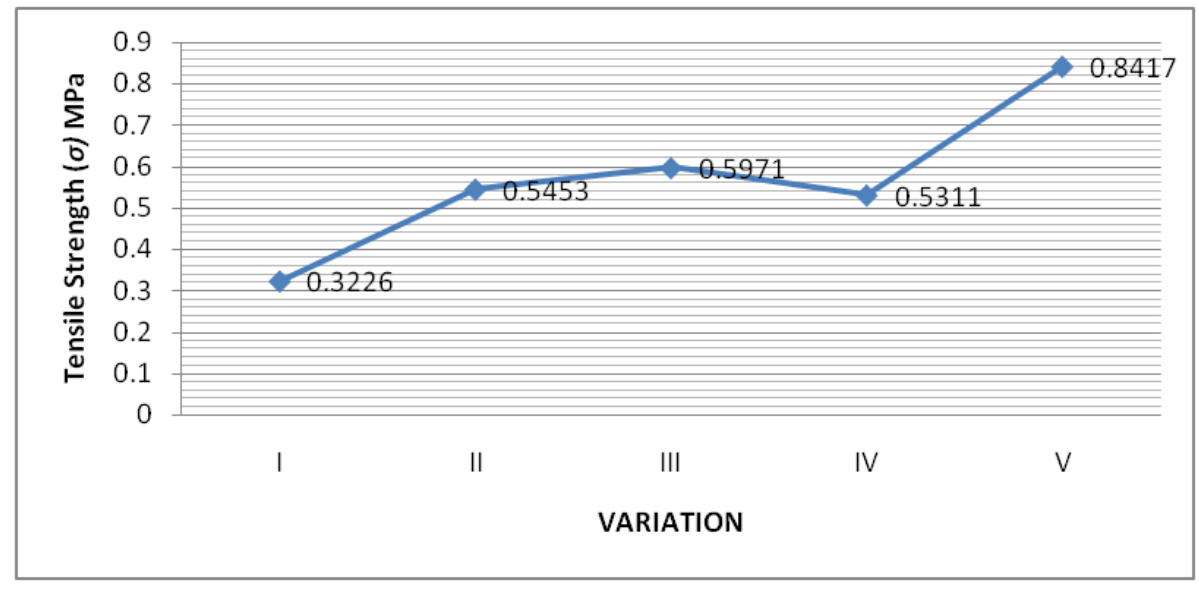

Figure 6 Graph of tensile strength

The use of fillers and natural fibers in the polymer matrix does provide advantages such as biodegradability, low cost, recycle ability and low density. However, on the one hand, it also shows a drawback, namely that it requires modification of the surface of the material so that the adhesion properties between the fiber and the matrix increase [11]. Modifications that can be done are chemical treatments, such as alkaline treatment, silane treatment, acetylation treatment, benzoylation treatment and peroxide treatment. The effect of the chemical treatment is able to increase viscoelastic, tribology and also absorption of water [12].

In composite studies that use natural fibers or fillers from natural materials, chemical treatment should be carried out first so that the adhesion properties are better. Besides chemical treatment of these natural materials, it should be combined with other materials (metal powder) in order to obtain a minimum standard as a friction material from already set.

\subsection{The Microstructure}

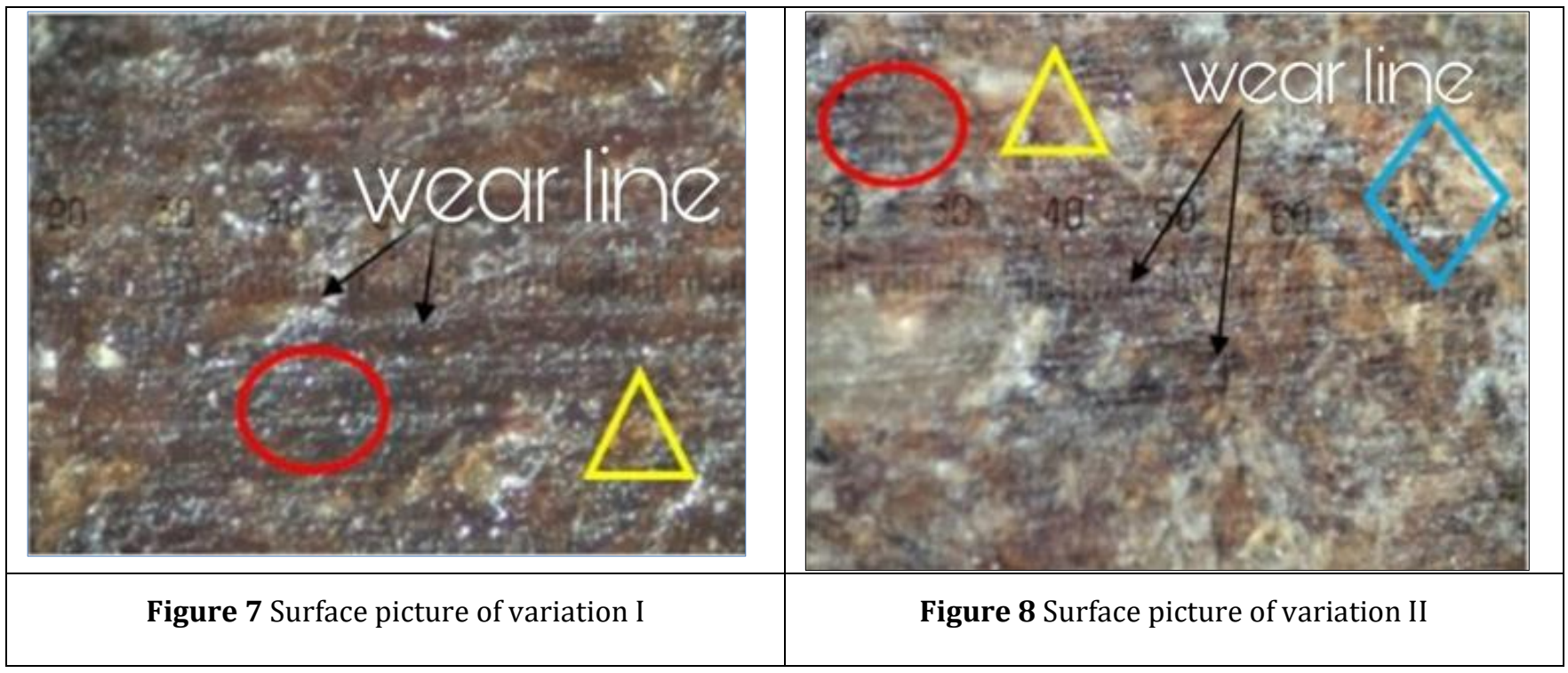




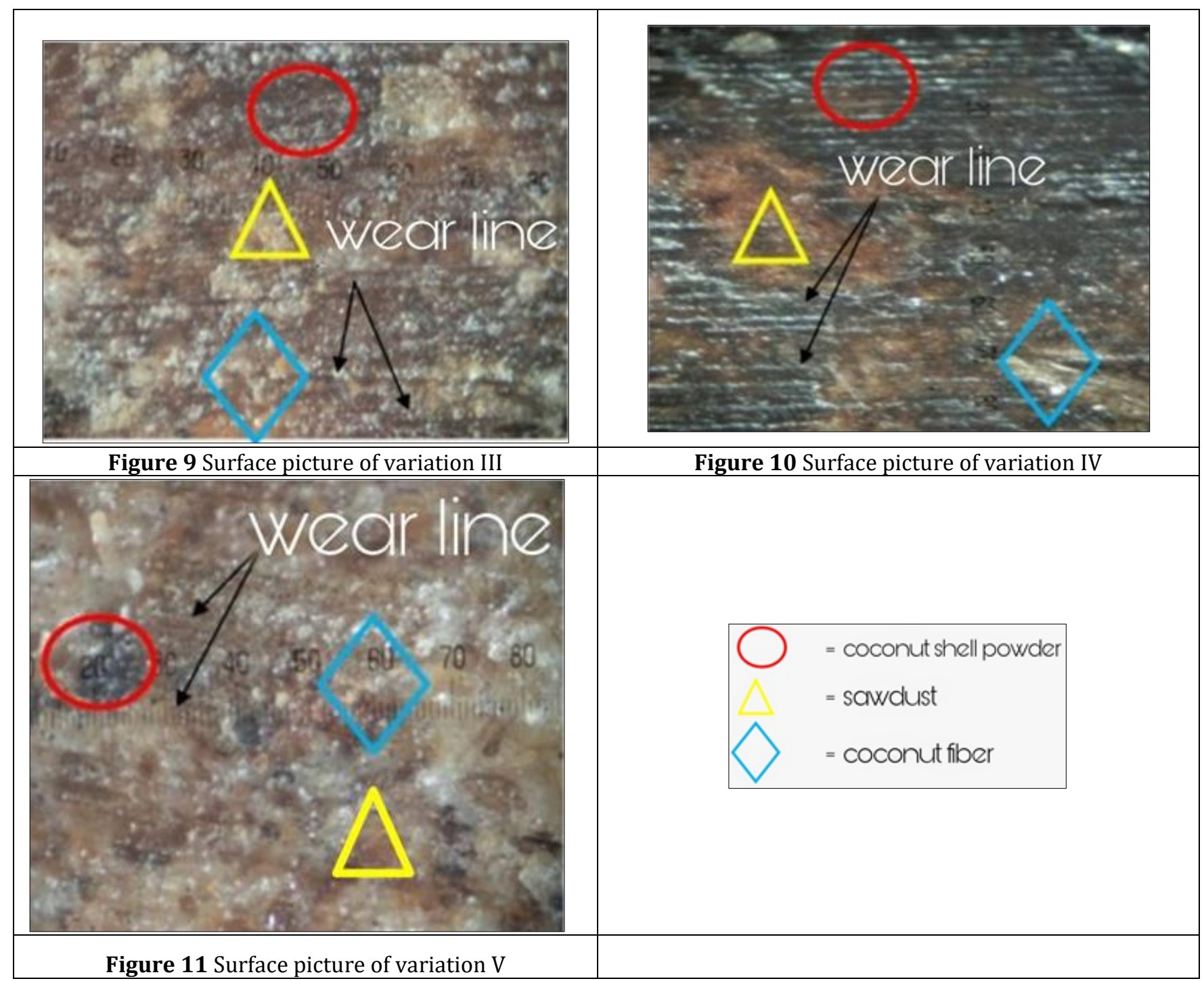

Physical observation of a composite is carried out to support the analysis of the properties possessed by the composite, where observation photos are taken before and after the wear test is carried out. This is done to determine the nature, structure and the effect of the percentage of the composite mixture on the wear resistance. Based on the results of surface observations using an optical microscope with 100 times magnification. The results of micros observation show where the wear path is visible from the I-V variation. The greater the percentage of the fiber volume, the width and depth of the wearer groove is getting smaller, so the wear value is getting smaller. The composition consists of coconut shell powder and sawdust as a filler, coconut fiber as a reinforce and phenolic as a binder. From each variation of the composition shows a difference which is indicated by the amount of composition between fillers, reinforcers, and binders that make up the specimen.

\section{Conclusion}

The best composition variation is in the $\mathrm{V}$ composition variation $(15 \%$ coconut Shell, $20 \%$ sawdust, $40 \%$ coconut fiber, and $25 \%$ Resin). The safety of the SAEJ 661 composite brake lining shows that the friction material products made in this study do not meet the standards. Differences in the structure of the variation in the volume fraction of the specimen making up the effect on the structure of the composite material. 


\section{Compliance with ethical standards}

\section{Acknowledgments}

The intellectual and moral contributions of Prof. Dr. Nasmi Herlina Sari, ST., MT., Prof. Dr. Tjok. Gde Tirta NindhiaI, ST, MT, M.ENG. Among others towards the success of this work are deeply appreciated.

\section{Disclosure of conflict of interest}

All authors of the manuscript have no conflict of interests to declare.

\section{References}

[1] ASTM D 638-03. " Standard Test Methods for Tensile Strength of Plastic", Philadelphia. N. 2002.

[2] Badan Pusat Statistik. "Statistik Perdagangan Luar Negeri Indonesia Impor", Jakarta. 1999.

[3] Cherie JW, Gibson H, McIntosh C, Maclaren WM, Linchae G. Exposure to Fire Airborne Dust Amongst Processor of Para-Aramid. Edinburgh: Institute of Occupational Medicine. 2000.

[4] Departemen Kehutanan dan Perkebunan, Panduan Kehutanan Indonesia, Departemen Kehutanan dan Perkebunan Republik Indonesia,: Jakarta. 1999/2000.

[5] Direktorat Jenderal Perkebunan. Data Lima Tahun Subsektor Perkebunan (2008-2012). 2013.

[6] Faisal, Hamid Tengku.Pengaruh Modifikasi Kimia terhadap Sifat -Sifat Komposit Polietilena Densitas Rendah( LDPE) Terisi Tempurung Kelapa, Tesis Program Pascasarjana, Universitas Sumatera Utara: Medan. 2008.

[7] Ginting, AX. The relation between wood waste management and the risk of transboundary haze from forest. 1998.

[8] Jorge Rencoret, John Ralph, Gisela Marques, Ana Gutierrez, Angel T. Martinez Dan Jose C. Del Rio, "Structural Characterization Of Lignin Isolated From Coconut (Cocos Nucifera) Coir Fibers", Journal Or Agricultural And Food Chemistry. 2013; 61: 2434-2445.

[9] Jacquer L. Durability of organic-matrix composite materials, JEC composite magazine. 2015.

[10] Kenneth G, dan Michael K. Engineering Materials. Upper River, New Jersey. 1999.

[11] Kabir MM, Wang H, Aravinthan T, Cardona F, Lau KT. Effects of Natural Fibre Surface on Composite Properties (Review), eddBE2011 Proceedings. 2011.

[12] Layth M, MNM Anshari, M Pua, M jawaid, M Saiful Islam. A Review Article: A Review and natural fiber reinforced polymer composite and its applications, International journal of polymer science. 2015.

[13] Louis St. U.S. Survey Shows Imports of Asbestos Brake Materials Increasing. St. Louis: Legal News Watch. 2004.

[14] Maryam. Laporan Praktikum Kimia, Fakultas Matematik adan Ilmu Pengetahuan Alam, Universitas Negeri Semarang. 2011.

[15] Oey Djoen Seng. Berat Jenis Dari Jenis-jenis Kayu Indonesia dan Pengertian Beratnya Kayu Untuk Keperluan Praktek. Pengumuman No. 1. Lembaga Penelitian Hasil Hutan, Bogor. 1964.

[16] Sirait DH. Material Komposit Berbasis Polimer Menggunakan Serat Alami. Dipetik Februari 5, 2016. 